\title{
Production and characterization of a thermostable beta-propeller phytase from Bacillus licheniformis
}

\author{
Yumao Wang ${ }^{1}$, Yichun $\mathrm{Wu}^{2}$, Jing Han ${ }^{3}$, Shijun $\mathrm{Fu}^{1,2}$, Shijin Guo' and Zhiqiang Shen ${ }^{1,2,3 *}$ \\ ${ }^{1}$ Shandong Binzhou Animal Science and Veterinary Medicine Academy, Binzhou 256600, People's Republic of China. \\ ${ }^{2}$ Biological Engineering College of Binzhou Polytechnic, Binzhou 256600, People's Republic of China. \\ ${ }^{3}$ Binzhou Preferential Hospital, Binzhou 256600, People's Republic of China.
}

Accepted 25 March, 2013

\begin{abstract}
A novel beta-propeller phytase producing thermophilic strain of Bacillus licheniformis was isolated. The culture conditions for production of phytase by $B$. licheniformis under shake flask culture were optimized to obtain high levels of phytase $(0.267 \mathrm{U} / \mathrm{ml})$. The optimum temperature and $\mathrm{pH}$ of the phytase from B. licheniformis (PhyC) were $55^{\circ} \mathrm{C}$ and 7.0 , respectively. The enzyme exhibited good thermostability and $\mathrm{pH}$ stability in the presence of $1 \mathrm{mM} \mathrm{CaCl}_{2}$. After treatment at $80^{\circ} \mathrm{C}, \mathrm{pH} 7.0$ for $10 \mathrm{~min}$, the residual activity of PhyC was $57.36 \%$. Over $\mathbf{8 0} \%$ of PhyC activity was retained after treatment by preincubation over a pH range of 6.5 to 9.0 for $1 \mathrm{~h}$ at $25^{\circ} \mathrm{C}$. Substrate was very specific for sodium phytate and showed no activity on other phosphate esters. Its activity was greatly inhibited by EDTA and metal ions such as $\mathrm{Cd}^{2+}, \mathrm{Mn}^{2+}, \mathrm{Cu}^{2+}$ and $\mathrm{Ba}^{2+}$.
\end{abstract}

Key words: Bacillus licheniformis, phytase, production, optimization, characterization.

\section{INTRODUCTION}

Phosphorus is one of the necessary mineral nutrients for animals during their growth, reproduction and calcification of the bones. The major storage form of phosphorus in plant seeds is phytate (myo-inositol-hexakisphosphate). Monogastric animals, such as swine and poultry, as well as fish, are unable to utilize phytate due to little or no intestinal phytase activity in their digestive tracts (Reddy et al., 1982). To prevent dietary phosphorus deficiency, inorganic phosphate is commonly added to the feed for the purpose of phosphorus supplementation (Wyss et al., 1999; Mullaney and Ullah, 2005). In addition, undigested phytate reduces mineral bioavailability and impairs protein digestibility in the animal (Maenz, 2001). The undigested phytate and the unabsorbed inorganic phosphorus in monogastric derived faeces have the potential to cause phosphorus pollution in areas of intensive animal production (Ullah et al., 2003; Chen et al., 2004).

Phytases (myo-inositol hexakisphosphate phosphohydrolase; EC 3.1.3.8 or EC 3.1.3.26) are a group of enzymes that catalyze the sequential hydrolysis of phytate in a stepwise manner to lower inositol phosphate, myo-inositol and inorganic phosphate (Mitchell et al., 1997; Farhat et al., 2008). This hydrolytic reaction plays an important role in energy metabolism, metabolic regulation and signal transduction pathways in biological system (Vats and Banerjee, 2002). More recently, increasing public concern regarding the environmental impact of high phosphorus levels in animal faeces has driven phytase application in animal feed and the biotechnological development of phytase (Lei and Stahl, 2001).

Phytases can be derived from a host of sources including plants (Maugenest et al., 1997), animals (Craxton et al., 1997) and microorganisms (Dassa et al., 1990; Ostanin et al., 1992; Rao et al., 2008), however, microbial sources are more promising for the production of phytases on a commercial scale. A wide variety of microbial phytases have been identified and characterized 
during the last decade, with a few of these phytases, from Aspergillus spp. and Peniophora lycii, being used as feed additives (Simon and Igbasan, 2002; Haefner et al., 2005). On the basis of $\mathrm{pH}$ profile, higher thermostability, and strict substrate specificity as well as physiological nature of phytate in digestive tract, neutral phytases from Bacillus species are considered ideal candidates for application in animal feed (Oh et al., 2004; Fu et al., 2008; Guerrero-Olazarán et al., 2010).

This paper describes the identification and production in submerged fermentation of thermostable beta-propeller phytase from a thermophilic strain of Bacillus licheniformis and characterization of the enzyme in terms of its potential application as a feed additive.

\section{MATERIALS AND METHODS}

\section{Phytase assay}

Phytase activity was determined according to the method described by Heinonen and Lahti (Heinonen and Lahti, 1980) with appropriate modification. Enzyme $(100 \mu \mathrm{l})$ and substrate $(900 \mu \mathrm{l} 0.1 \%(\mathrm{w} / \mathrm{v})$ sodium phytate in $0.2 \mathrm{M}$ Tris- $\mathrm{HCl}$ buffer $(\mathrm{pH} 7.0)$ supplemented with $1 \mathrm{mM} \mathrm{CaCl}_{2}$ ) were co-incubated at $55^{\circ} \mathrm{C}$ for $30 \mathrm{~min}$. One unit of phytase activity $(1.0 \mathrm{lU})$ is defined as the amount of enzyme that catalyses the production of $1 \mu \mathrm{mol}$ inorganic phosphate per minute under the standard assay conditions. Protein concentration was measured by the dye-binding assay method of Bradford (1976), and bovine serum albumin (BSA) was used as the standard.

\section{Isolation and identification of neutral phytase-producing} strains

The local soil samples were suitably diluted and spread onto phytase screening culture medium (SCM) for selecting phytase-producing bacteria. The SCM contained (\%; w/v): Calcium phytate, $0.5 ; \mathrm{NH}_{4} \mathrm{NO}_{3}, 0.5 ; \mathrm{KCl}, 0.5 ;$ glucose, $3.0 ; \mathrm{MgSO}_{4} \cdot 7 \mathrm{H}_{2} \mathrm{O}, 0.05$ $\mathrm{MnSO}_{4} \cdot 4 \mathrm{H}_{2} \mathrm{O}, 0.03 ; \mathrm{FeSO}_{4} \cdot 7 \mathrm{H}_{2} \mathrm{O}, 0.03$; and agar 2.0, pH 7.0. The isolates showing clear zones on phytate screening medium were further screened on submerged fermentation medium (SFM) of the following composition (\%; w/v): glucose, 2.0; $\mathrm{NH}_{4} \mathrm{NO}_{3}, \quad 0.2$; $\mathrm{MgSO}_{4} \cdot 7 \mathrm{H}_{2} \mathrm{O}, 0.05 ; \mathrm{KCl}, 0.05 ; \mathrm{FeSO}_{4} \cdot 7 \mathrm{H}_{2} \mathrm{O}, 0.001 ; \mathrm{MnSO}_{4} \cdot 4 \mathrm{H}_{2} \mathrm{O}$ 0.001 ; and $\mathrm{CaCl}_{2}, 0.2, \mathrm{pH}$ 7.0. The sterile production medium $(50 \mathrm{ml})$ in $250 \mathrm{ml}$ conical flasks was inoculated with $12 \mathrm{~h}$ old cultures grown on LB medium at $2 \%(\mathrm{v} / \mathrm{v})$, and incubated under shaking conditions $(120 \mathrm{rpm})$ at $55^{\circ} \mathrm{C}$ for $24 \mathrm{~h}$. The fermented broth was clarified by centrifugation at $10000 \mathrm{rpm}$ for $10 \mathrm{~min}$ and assayed for phytase activity. The selected cultures were maintained on nutrient agar medium and stored at $4^{\circ} \mathrm{C}$.

\section{Optimization of phytase production under shake flask cultures}

\section{Effect of various carbon sources on the production of phytase by $B$. licheniformis}

The effect of various carbon sources (at $1 \% \mathrm{w} / \mathrm{v}$ ), that is, glucose, sucrose, lactose, maltose, cellulose, dextrine, wheat bran, potato flour, corn flour and rice bran on the production of phytase by $B$. licheniformis was studied. The flasks were inoculated with actively growing culture and incubated at $55^{\circ} \mathrm{C}$ under shaking $(120 \mathrm{rpm})$ for $48 \mathrm{~h}$.

\section{Effect of various nitrogen sources on the production of phytase} by $B$. licheniformis

Effect of different nitrogen sources (at $0.1 \% \mathrm{w} / \mathrm{v})$ : $\left(\mathrm{NH}_{4}\right)_{2} \mathrm{SO}_{4}, \mathrm{NH}_{4} \mathrm{Cl}$, $\mathrm{NH}_{4} \mathrm{NO}_{3}$, urea, beef extract, yeast extract, peptone, soybean meal, rapeseed meal and cottonseed meal on phytase production was studied by replacing $\mathrm{NH}_{4} \mathrm{NO}_{3}$ in submerged fermentation medium.

\section{Effect of initial $\mathrm{pH}$ on the production of phytase by $B$. licheniformis}

The influence of initial $\mathrm{pH}$ of the medium on the production of phytase was studied between $\mathrm{pH} 4.0$ and 10.0.

\section{Effect of temperature on the production of phytase by $B$. licheniformis}

The effect of incubation temperature on phytase production was studied between 20 and $70^{\circ} \mathrm{C}$ in the production medium with optimal $\mathrm{pH}$ of 7.5 .

\section{Effect of incubation period on the production of phytase by $B$. licheniformis}

Various incubation periods $(12,24,36,48,60,72$ and $84 \mathrm{~h})$ were assayed, tested, studied and the fermentation was performed with all other parameters kept at their optimum levels.

\section{Characterization of phytase from B. licheniformis}

\section{Temperature and pH optima}

The temperature profile of the phytase was obtained by determining the activity on sodium phytate between 30 and $90^{\circ} \mathrm{C}$ at 5 -degree intervals. The optimal $\mathrm{pH}$ was determined by measuring the activity between $\mathrm{pH} 2.0$ and $9.0(0.2 \mathrm{M})$ using glycine- $\mathrm{HCl}(\mathrm{pH} 2.0$ and 3.0),

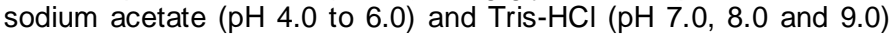
buffers at $55^{\circ} \mathrm{C}$.

\section{Thermostability and $\mathrm{pH}$ stability}

For the determination of thermostability and $\mathrm{pH}$ stability, the enzyme was pre-incubated (with or without $1 \mathrm{mM} \mathrm{CaCl}_{2}$ ) at 30 to $90^{\circ} \mathrm{C}$ for 10 min and $\mathrm{pH}$ of 2.0 to 9.0 for $1 \mathrm{~h}$, the residual phytase activity was assayed using sodium phytate as substrate.

\section{Effect of metal ions and reducing compounds}

The effect of metal ions and reducing compounds on phytase activity was examined with sodium phytate as a substrate after removal of $\mathrm{Ca}^{2+}$. Phytase was incubated in 1 and $5 \mathrm{mM}$ of $\mathrm{CuCl}_{2}$, $\mathrm{ZnCl}_{2}, \mathrm{MgCl}_{2}, \mathrm{MnCl}_{2}, \mathrm{LiCl}_{2}, \mathrm{CaCl}_{2}, \mathrm{CdCl}_{2}, \mathrm{BaCl}_{2}, \mathrm{EDTA}$, DTT and PMSF for $30 \mathrm{~min}$ at room temperature.

\section{Substrate specificity}

The substrate specificity of the enzyme was tested against different types of phosphate substrates $(2 \mathrm{mM})$ : Na-phytate, tripolyphosphate, $\alpha$-Glycerophosphate, $\beta$-Glycerophosphate, $\rho$-nitrophenyl phosphate, a-Naphthyl phosphate, AMP, ADP and ATP by incubating the enzyme separately with the substrates and measuring the amount of released phosphorus as described above. 


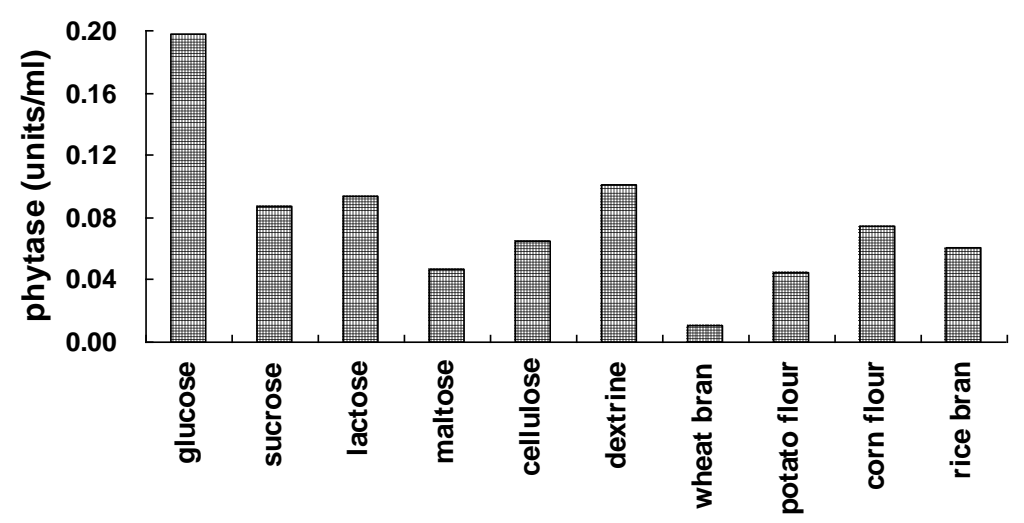

Figure 1. Effect of various carbon sources on phytase production by $B$. licheniformis.

Analytical methods

\section{Statistical analysis}

One-way ANOVA followed by LSD post-hoc test was used to determine significant differences among treatment groups. For all analysis, differences were considered to be significant at $P<0.05$ (Steel and Torrie, 1980).

\section{RESULTS AND DISCUSSION}

\section{Isolation and screening of phytase producing bacteria}

A total of twelve phytase producing thermophilic bacteria were isolated on the basis of transparent zones formed on the opaque SCM medium containing Ca-phytate as a selective agent. The isolates showing clear zones on phytate screening medium were further screened in submerged fermentation medium, without Ca-phytate, for phytase production at $55^{\circ} \mathrm{C}$. Of the twelve isolates, strain designated as ZJ-6 produced the highest phytase $(0.1511$ $\mathrm{U} / \mathrm{ml}$ ) and was identified as $B$. licheniformis on the basis of 16S rRNA sequence analysis. Several Bacillus species such as Bacillus sp. DS11 (Kim et al., 1998), Bacillus subtilis (Kerovuo et al., 1998), Bacillus sp. KHU-10 (Choi et al., 1999), Bacillus laevolacticus (Gulatih et al., 2007) that produce thermostability beta-propeller phytase were isolated from soil.

\section{Optimization of phytase production under shake flask cultures}

\section{Effect of various carbon sources on the production of phytase by $B$. licheniformis}

Of the various carbon sources, glucose was able to support maximal phytase expression $(0.1987 \mathrm{U} / \mathrm{ml})$ (Figure 1). Earlier reports suggest wheat bran as a suitable carbon source for phytase production by Bacillus amyloliquefaciens DS11, $B$. subtilis, and $B$. amyloliquefaciens FZB45 (Kim et al., 1998; Kerovuo et al., 1998; Idriss et al., 2002), sucrose as a suitable carbon source for phytase production in Bacillus laevolacticus (Gulatih et al., 2007). Batal and Karem (2001) reported that adding glucose at level of $6 \%$ in solid state fermentation resulted in the highest enzyme production and higher glucose concentrations (10 and 20\%) inhibited the enzyme production.

\section{Effect of various nitrogen sources on the production of phytase by B. licheniformis}

When $\mathrm{NH}_{4} \mathrm{NO}_{3}$ was replaced in the production medium with $\left(\mathrm{NH}_{4}\right)_{2} \mathrm{SO}_{4}$, as compared to other nitrogen sources, it showed dramatic increase in phytase production $(0.218$ $\mathrm{U} / \mathrm{ml}$ ) (Table 1). The results of the present study showed that $\left(\mathrm{NH}_{4}\right)_{2} \mathrm{SO}_{4}$ could stimulate high-phytase production.

\section{Effect of initial $\mathrm{pH}$ on the production of phytase by $B$. licheniformis}

The phytase production was studied over a $\mathrm{pH}$ range of 4.0 to 10.0 . A pH of 7.5 was found optimal for phytase production (Figure 2). The production of phytase at $\mathrm{pH} 6.0$ to 10.0 was not severely affected and sharply declined when $\mathrm{pH}$ level was below 6.0. On the contrary, Lan et al. (2002) reported that phytase production and bacterial growth were significantly inhibited when $\mathrm{pH}$ level of the medium was lower than 6.8.

Effect of incubation temperature and period on the production of phytase by B. licheniformis

The optimal incubation temperature for phytase 
Table 1. Effect of various nitrogen sources on phytase production by $B$. licheniformis.

\begin{tabular}{lc}
\hline Nitrogen sources & Phytase (U/mI) \\
\hline$\left(\mathrm{NH}_{4}\right)_{2} \mathrm{SO}_{4}$ & $0.218 \pm 0.003$ \\
$\mathrm{NH}_{4} \mathrm{Cl}$ & $0.178 \pm 0.002$ \\
$\mathrm{NH}_{4} \mathrm{NO}_{3}$ & $0.104 \pm 0.005$ \\
beef extract & $0.126 \pm 0.003$ \\
urea & $0.014 \pm 0.009$ \\
yeast extract & $0.074 \pm 0.004$ \\
peptone & $0.022 \pm 0.002$ \\
soybean meal & $0.136 \pm 0.003$ \\
rapeseed meal & $0.019 \pm 0.001$ \\
cottonseed meal & $0.067 \pm 0.003$ \\
\hline
\end{tabular}

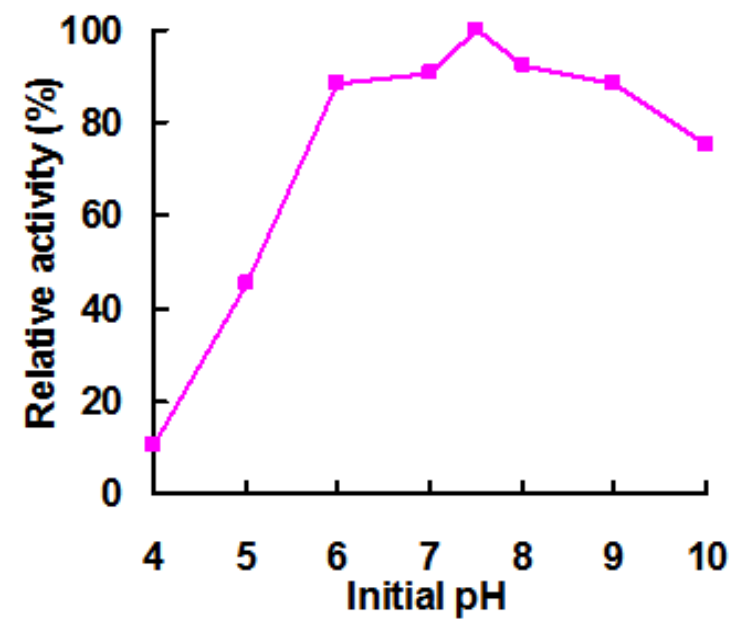

Figure 2. Effect of initial pH on phytase production by $B$. licheniformis.

production by $B$. licheniformis was found to be $55^{\circ} \mathrm{C}$ (Figure 3). This result was different from earlier reports. The optimal temperature for phytase production by $B$. laevolacticus was $50^{\circ} \mathrm{C}$ (Gulatih et al., 2007). The other reported Bacillus species such as Bacillus sp. KHU-10 (Choi et al., 2001), Bacillus sp. DS11 (Kim et al., 1998), B. subtilis (Kerovuo et al., 1998), produced maximal activity at $37^{\circ} \mathrm{C}$. The maximal phytase activity $(0.267 \mathrm{U} / \mathrm{ml})$ under the optimized conditions was achieved during late exponential phase after $36 \mathrm{~h}$ of incubation at $55^{\circ} \mathrm{C}$ (Figure 4). Choi et al. (2001) observed that Bacillus sp. KHU-10 produced the highest activity of phytase after 4 days of fermentation under optimized conditions.

\section{Characterization of the phytase from B. licheniformis}

\section{Temperature optimum and stability}

The optimum temperature was $55^{\circ} \mathrm{C}$ as shown in Figure 5 .

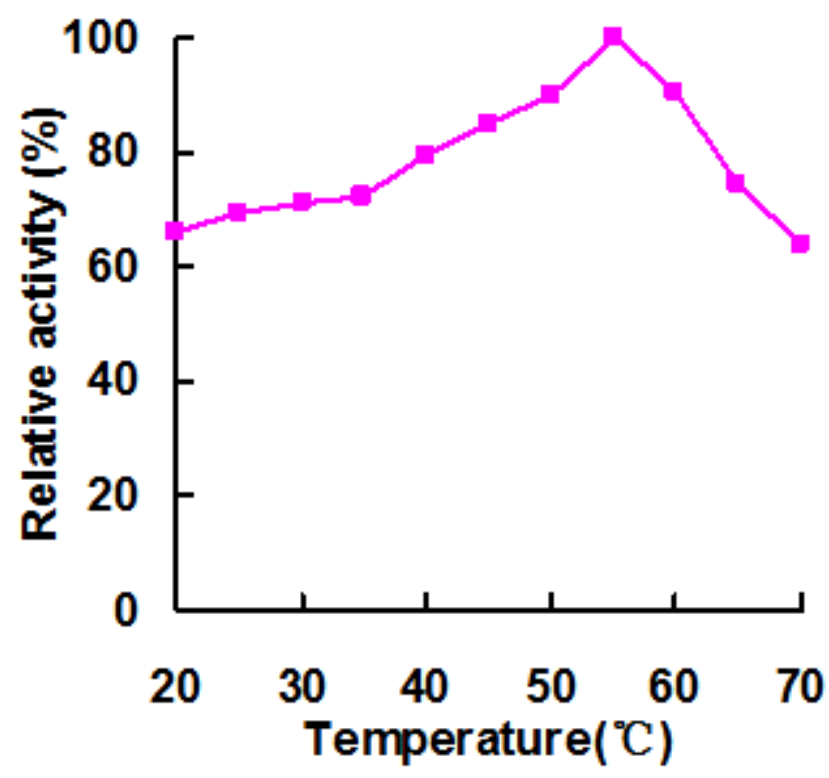

Figure 3. Effect of incubation temperature on phytase production by $B$. licheniformis.

To test the thermostability, the activity of the PhyC was measured after incubation at various temperatures for 10 min. The enzyme stability of the PhyC was drastically reduced above $40^{\circ} \mathrm{C}$ in the absence of $\mathrm{CaCl}_{2}$. After incubation at $80^{\circ} \mathrm{C}$ in the presence of $1 \mathrm{mM} \mathrm{CaCl}_{2}$ for 10 min, the remaining enzyme activity was $57.36 \%$ of the initial activity. These results indicated that $\mathrm{Ca}^{2+}$ ion has a stabilizing effect on the enzyme against thermal denaturation. This property would be very useful for the enzyme to withstand inactivation during feed-pelleting or the expansion process and decrease costly formulations to limit activity loss industrial applications.

\section{pH optimum and stability}

The phytase showed high activity at relatively broad $\mathrm{pH}$ range between $\mathrm{pH} 6.0$ and 8.0 in the reaction mixture (Figure 6). The addition of $1 \mathrm{mM} \mathrm{CaCl}$ to the incubated buffers made the enzyme more stable in the $\mathrm{pH}$ range of 5.0 to 9.0. In the presence of $1 \mathrm{mM} \mathrm{CaCl}_{2}$, the remaining enzyme activity was above $60 \%$ after incubation at $55^{\circ} \mathrm{C}$ for $1 \mathrm{~h}$. These results indicated that $\mathrm{Ca}^{2+}$ ion has an effect on enzyme activity against $\mathrm{pH}$.

\section{Effect of metal ions and reducing compounds on the PhyC}

The effect of reagents and metal ions on the enzyme activity was examined using sodium phytate as a substrate after removal of calcium ions in enzyme solution by dialysis (Table 2 ). The enzyme activity was greatly 


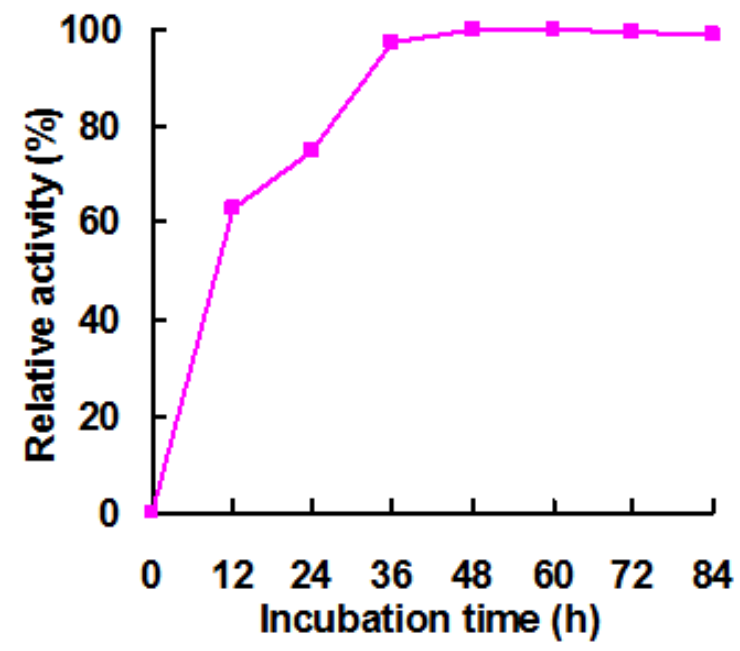

Figure 4. Effect of incubation time on phytase production by $B$. licheniformis.

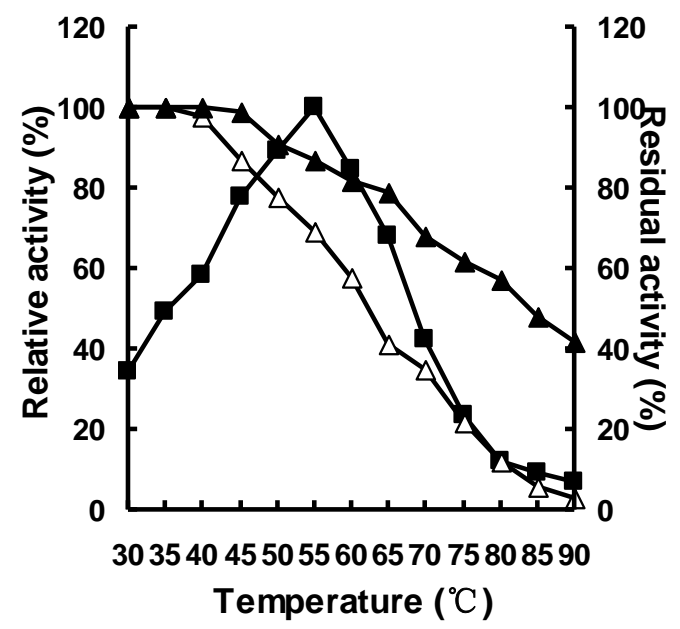

- Optimal temperature; $\Delta$ Without $\mathrm{Ca}^{2+} ; \mathbf{\Delta}$ With $1 \mathrm{mM} \mathrm{Ca}^{2+}$

Figure 5. Effect of temperature on the activity and stability of the PhyC. The enzyme activity was assayed at various temperatures. For thermostability, the enzyme was preincubated at various temperatures without/with $1 \mathrm{mM}$ $\mathrm{CaCl}_{2}$ for $10 \mathrm{~min}$.

inhibited by EDTA, $\mathrm{Cd}^{2+}, \mathrm{Mn}^{2+}, \mathrm{Cu}^{2+}$ and $\mathrm{Ba}^{2+}$. PMSF and DTT showed little effect on the enzyme activity. Removal of metal ions from the enzyme by EDTA resulted in complete inactivation. The loss of enzymatic activity was most likely due to a conformational change, as the circular dichroism spectra of holoenzyme and metal depleted enzyme were different (Kerovuo et al., 2000).

\section{Substrate specificity}

The substrate specificity of the PhyC on several phosphate

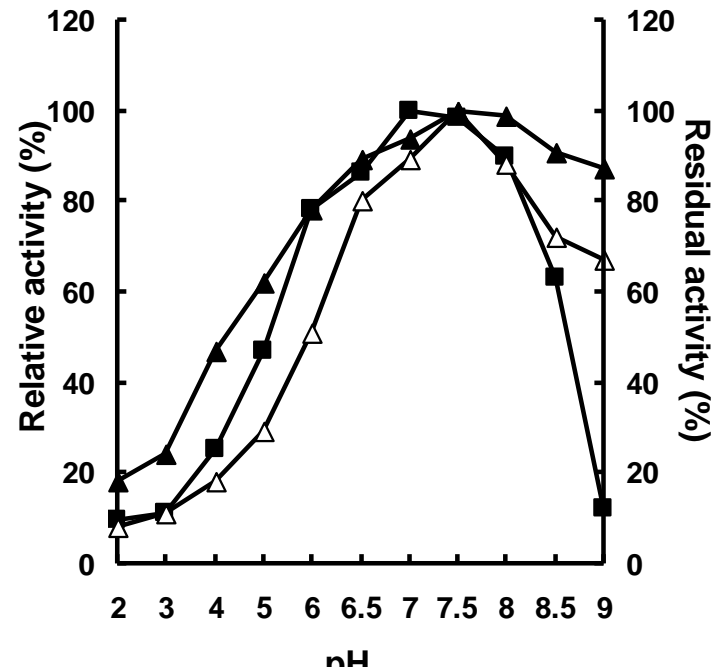

$\mathrm{pH}$

- Optimal $\mathrm{pH} ; \Delta$ Without $\mathrm{Ca}^{2+} ; \boldsymbol{\Delta}$ With $1 \mathrm{mM} \mathrm{Ca}^{2+}$

Figure 6. Effect of $\mathrm{pH}$ on the activity and stability of the PhyC. The enzyme was assayed at various $\mathrm{pH}$ buffers. For $\mathrm{pH}$ stability, the enzyme was pre-incubated at various $\mathrm{pH}$ buffers without/with $1 \mathrm{mM} \mathrm{CaCl}$ for $1 \mathrm{~h}$.

Table 2. Effect of metal ions and reagents on the activity of the Phyc.

\begin{tabular}{lcc}
\hline \multirow{2}{*}{ Reagents } & \multicolumn{2}{c}{ Relative activity (\%) } \\
\cline { 2 - 3 } & $\mathbf{1 ~} \mathbf{~ M}$ & $\mathbf{5 ~} \mathbf{~ M}$ \\
\hline None & 100 & 100 \\
$\mathrm{CuCl}_{2}$ & 66 & 49 \\
$\mathrm{ZnCl}_{2}$ & 77 & 69 \\
$\mathrm{MgCl}_{2}$ & 87 & 75 \\
$\mathrm{MnCl}_{2}$ & 66 & 26 \\
$\mathrm{LiCl}_{2}$ & 95 & 99 \\
$\mathrm{CaCl}_{2}$ & 112 & 98 \\
$\mathrm{CdCl}_{2}$ & 10 & 6 \\
$\mathrm{BaCl}$ & 72 & 37 \\
$\mathrm{EDTA}$ & 6 & 2 \\
$\mathrm{DTT}$ & 93 & 90 \\
PMSF & 89 & 88 \\
\hline
\end{tabular}

esters was tested in $0.1 \mathrm{M}$ Tris- $\mathrm{HCl}$ buffer $(\mathrm{pH} 7.0)$. Controls were run for determining initial phosphorus in each substrate. As summarized in Table 3, the enzyme had high activity for sodium phytate, but no activity on other phosphorylated compounds including sodium $\rho$-nitrophenyl phosphate, a general substrate for acid phosphatase. These results imply that the PhyC is specific for inositol polyphosphate. This property made the PhyC distinct from $B$. subtilis phytase, which has hydrolytic activity on some inorganic compounds as well 
Table 3. Substrate specificity of the PhyC.

\begin{tabular}{lc}
\hline Substrate (2 mM) & $\begin{array}{c}\text { Relative } \\
\text { activity }(\%)\end{array}$ \\
\hline Sodium phytate & 100 \\
Sodium tripolyphosphate & 8 \\
Sodium pyrophosphate & 0 \\
Sodium a-Glycerophosphate & 0 \\
Sodium $\beta$-Glycerophosphate & 0 \\
Sodium $\rho$-nitrophenyl phosphate & 0 \\
Sodium $\alpha$-Naphthyl phosphate & 0 \\
ATP & 0 \\
ADP & 0 \\
AMP & 0 \\
\hline
\end{tabular}

as phytate (Shimizu, 1992).

\section{Conclusions}

In this study, a novel beta-propeller phytase producing thermophilic strain of $B$. licheniformis was isolated. The optimal fermentation parameters for producing phytase by $B$. licheniformis were determined by single factor test. Glucose and $\left(\mathrm{NH}_{4}\right)_{2} \mathrm{SO}_{4}$ were the most suitable carbon and nitrogen source for phytase production from $B$. licheniformis, respectively. The optimal fermentation conditions were: initially $\mathrm{pH} 7.5$, incubation temperature $55^{\circ} \mathrm{C}$. The culture conditions for production of phytase by $B$. licheniformis under shake flask culture were optimized to obtain high levels of phytase $(0.267 \mathrm{U} / \mathrm{ml})$.

The optimum temperature and $\mathrm{pH}$ of the phytase from $B$. licheniformis (PhyC) were $55^{\circ} \mathrm{C}$ and 7.0 , respectively. The enzyme exhibited good thermostability and $\mathrm{pH}$ stability in the presence of $1 \mathrm{mM} \mathrm{CaCl}_{2}$. After treatment at $80^{\circ} \mathrm{C}, \mathrm{pH}$ 7.0 for $10 \mathrm{~min}$, the residual activity of PhyC was $57.36 \%$. Over $80 \%$ of PhyC activity was retained after treatment by preincubation over a pH range of 6.5 to 9.0 for $1 \mathrm{~h}$ at $25^{\circ} \mathrm{C}$. Substrate was very specific for sodium phytate and showed no activity on other phosphate esters. Its activity was greatly inhibited by EDTA and metal ions such as $\mathrm{Cd}^{2+}, \quad \mathrm{Mn}^{2+}, \quad \mathrm{Cu}^{2+}$ and $\mathrm{Ba}^{2+}$. The higher temperature-stability of the rePhyCm suggests that it may be a potentially better candidate in commercial and environmental applications.

\section{REFERENCES}

Batal Al, Karem HA (2001). Phytase production and phytic acid reduction in rapeseed meal by Aspergillus niger during solid state fermentation. Food Res. Int. 34:715-720.

Bradford MM (1976). A rapid and sensitive method for the quantitation of microgram quantities of protein utilizing the principle of protein-dye binding. Anal. Biochem. 72:248-254.

Chen CC, Wu PH, Huang CT, Cheng KJ (2004). A Pichia pastoris fermentation strategy for enhancing the heterologous expression of an Escherichia coli phytase. Enzyme Microb. Technol. 35:315-320.

Choi YM, Noh DO, Cho SH, Lee HK, Suh HJ, Chung SH (1999). Isolation of a phytase-producing Bacillus sp. $\mathrm{KHU}-10$ and its phytase production. J. Microbiol. Biotechnol. 9:223-226.

Choi YM, Suh HJ, Kim JM (2001). Purification and properties of extracellular phytase from Bacillus sp. KHU-10. J. Protein Chem. 20:287-292.

Craxton A, Caffrey JJ, Burkhart W, Safrany ST, Shears SB (1997). Molecular cloning and expression of a rat hepatic multiple inositol polyphosphate phosphatase. Biochem. J. 328:75-81.

Dassa J, Marck C, Boquet PL (1990). The complete nucleotide sequence of the Escherichia coli gene appA reveals significant homology between $\mathrm{pH} 2.5$ acid phosphatase and glucose-1-phosphatase. J. Bacteriol. 172:5497-5500.

Farhat AH, Chouayekh MB, Farhat K, Bouchaala, Bejar S (2008). Gene cloning and characterization of a thermostable phytase from Bacillus subtilis US417 and assessment of its potential as a feed additive in comparison with a commercial enzyme. Mol. Biotechnol. 40:127-135.

Fu SJ, Sun JY, Qian LC (2008). Effect of $\mathrm{Ca}^{2+}$ on beta-propeller phytases. Protein Peptide Lett. 15:39-42.

Guerrero-Olazarán M, Rodríguez-Blanco L, Carreon-Treviño JG, Gallegos-López JA, Viader-SalvadóJ M (2010). Expression of a Bacillus phytase $\mathrm{C}$ gene in Pichia pastoris and properties of the recombinant enzyme. Appl. Environ. Microbiol. 76: 5601-5608.

Gulatih K, Chadha BS, Saini HS (2007). Production and characterization of thermostable alkaline phytase from Bacillus laevolacticus isolated from rhizosphere soil. J. Ind. Microbiol. Biotechnol. 34:91-98.

Haefner S, Knietsch A, Scholten E, Braun J, Lohscheidt M, Zelder O (2005). Biotechnology production and applications of phytases. Appl. Microb. Biotechnol. 68:588-597.

Heinonen J, Lahti R (1980). A new and convenient colorimetric determination of inorganic orthophosphate and its application to the assay of inorganic pyrophosphate. Anal. Biochem. 113:313-317.

Idriss EE, Makarewicz O, Farouk A, Rosner K, Greiner R, Bochow H, Richter T, Borriss R (2002). Extracellular phytase activity of Bacillus amyloliquefaciens FZB45 contributes to its plant-growth-promoting effect. Microbiology 148:2097-2109.

Kerovuo J, Lappalainen I, Reinikainen T (2000). The metal dependence of Bacillus subtilis phytase. Biochem. Biophys. Res. Commun. 268:365-369.

Kerovuo J, Lauraeus M, Nurminen P, Kalkkinen N, Apajalahti J (1998). Isolation characterization molecular gene cloning and sequencing of a novel phytase from Bacillus subtilis. Appl. Environ. Microb. 64:2079-2085.

Kim YO, Kim HK, Bae KS, Yu JH, Oh TK (1998). Purification and properties of thermostable phytase from Bacillus sp. DSII. Enzyme Microb. Technol. 22:2-7.

Lan GQ, Abdullah N, Jalaludin S, Ho YW (2002). Culture conditions influencing phytase production of Mitsuokella jalaludinii, a new bacteria species from the rumen of cattle. J. Appl. Microbiol. 93:668-674.

Lei XG, Stahl CH (2001). Biotechnological development of effective phytases for mineral nutrition and environmental protection. Appl. Microbiol. Biotechnol. 57:474-481.

Maenz D (2001). Enzymatic characteristics of phytases as they relate to their use in animal feeds. Enzymes in Farm Animal Nutrition, CABI Publishing, Oxon, UK.

Maugenest S, Martinez I, Lescure A (1997). Cloning and characterization of a cDNA encoding a maize seedling phytase. $J$ Biochem. 322:511-517.

Mitchell DB, Vogel K, Weimann B, Pasamontes L, von Loon APGM (1997). The phytase subfamily of histidine acid phosphatases: isolation of genes for two novel phytases from the fungi Aspergillus terreus and Myceliophthora thermophola. Microbiology 143:245-252.

Mullaney EJ, Ullah AHJ (2005). Conservation of cysteine residues in fungal histine acid phytases. Biochem. Biophys. Res. Commun. 328:404-408.

Oh BC, Choi WC, Park S, Kim YO, Oh TK (2004). Biochemical properties and substrate specificity of alkaline and histidine acid phytases. Appl. Microbiol. Biotechnol. 63:362-372.

Ostanin K, Harms EH, Stevis PE, Kuciel R, Zhou MM, Van-Etten RL (1992) Overexpression, site-directed mutagenesis, and mechanism of 
Escherichia coli acid phosphatase. J. Biol. Chem. 267:22830-22836.

Rao DE, Rao KV, Reddy VD (2008). Cloning and expression of Bacillus phytase gene (phy) in Escherichia coli and recovery of active enzyme from the inclusion bodies. J. Appl. Microbiol. 105:1128-1137.

Reddy NR, Sathe SK, Salunkhe DK (1982). Phytates in legumes and cereals. Adv. Food Res. 28:1-92.

Shimizu M (1992). Purification and characterization of phytase from Bacillus subtilis (natto) N-77. Biosci. Biotechnol. Biochem. 56:1266-1269.

Simon O, Igbasan $F$ (2002). In vitro properties of phytase from various microbial origins. Int. J. Food Sci. Technol. 37:813-822.

Steel RGD, Torrie JH (1980). Principle and procedure of statistics. In: A Biochemical Approach, 2nd ed., McGraw- Hill Booh Company, New York.
Ullah AHJ, Sethumadhavan K, Mullaney EJ, Ziegelhoffer T, Austin-Phillips $S$ (2003). Fungal phyA gene expressed in potato leaves produces active and stable phytase. Biochem. Biophys. Res. Commun. 306: 603-609.

Vats P, Banerjee UC (2002). Studies on the production of phytase by a newly isolated strain of Aspergillus niger van teigham obtained from rotten wood logs. Process Biochem. 38:211-217.

Wyss M, Brugger R, Kronenberger A, Remy R, Fimbel R, Oesterhelt G, Lehmann M, van Loon APGM (1999). Biochemical characterization of fungal phytases (myo-inositol hexakisphosphate phosphorhydrolases): catalytic properties. Appl. Environ. Microb. 65:367-373. 